\title{
The Barriers to and Directions of Cross-Border Cooperation in the Northern Part of the Polish-German Borderland
}

Keywords: barriers to cross-border cooperation, directions of cross-border cooperation, Cooperation Programme Interreg VA, Polish-German borderland

Słowa kluczowe: bariery współpracy transgranicznej, kierunki współpracy transgranicznej, Program Współpracy Interreg VA, pogranicze polsko-niemieckie

\section{Introduction}

Throughout the years, the significance of cross-border cooperation in the European Union has been growing. The intensification of the related actions has been determined by EU funds. ${ }^{1}$ As a consequence of that, the issues of the cross-border cooperation have become one of the three objectives of EU regional policy, mainly supported by such financial instruments as Interreg Initiatives. They constitute a foundation on which other forms of the cooperation, both formal and informal, are built, and due to the amounts of funds involved, as well as the numbers of actors, and the multitude of the potential areas of the cooperation, they reflect the true status and the directions of the cooperation in the border areas. ${ }^{2}$ The cross-border cooperation has become an important tool used

* Dr Agnieszka Malkowska, adiunkt na Wydziale Zarządzania i Ekonomiki Usług Uniwersytetu Szczecińskiego e-mail: agnieszka.malkowska@wzieu.pl.

1 See, e.g., M. Perkmann, Building governance institutions across European borders, Regional Studies 1999, vol. 33, no. 7, p. 657-667; Wspótpraca transgraniczna Unii Europejskiej. Doświadczenia polsko-niemieckie, eds. G. Gorzelak, J. Bachtler, M. Kasprzyk, Wydawnictwo Naukowe Scholar, Warszawa 2004.

2 S. Dołzbłasz, A. Raczyk, Projekty wspótpracy transgranicznej na zewnętrznych $i$ wewnętrznych granicach Unii Europejskiej - przykład Polski, "Studia Regionalne i Lokalne" 2011, no. 3 (45), p. 60. 
by the border regions, widely perceived as the problem areas, ${ }^{3}$ to eliminate any barriers and limitations between the lands divided by the border.

The genesis of the cross-border cooperation in the northern part of the Polish-German borderland has inseparably been tied with the difficult history of this place. It is indicated that the first official contacts between the towns and municipalities of the then Województwo Szczecińskie (Szczecin Voivodeship) and Mecklenburg-Vorpommern took place in early $1991 .{ }^{4}$ It must be added that since the beginning, the parties also undertook actions aimed at creating a Euroregion here, which is considered to be the highest (institutionalised) form of the cross-border ties. The agreement establishing the Pomerania Euroregion was signed on 15 December 1995.

The cross-border cooperation in the Polish western borderland is considered to be the best, and is pointed to as the model example of how to build contacts between the neighbours living on the opposite sides of the internal borders of the expanded EU. ${ }^{5}$ Funds have been allocated to Polish-German cooperation programmes since as early as $1994,{ }^{6}$ and they have been clearly larger than those allocated to the programmes run for other borderlands. Thanks to that, some of the barriers to the cross-border cooperation in our western borderland have been eliminated or reduced?

The new EU financial framework for the years 2014-2020 is another opportunity for improving the cross-border cooperation, thereby developing the Polish-German borderland. Thus, the question arises of what barriers and limitations the Polish and German sides will have to face when continuing their cooperation. The objective of this paper is to identify them at the threshold of the new programming period, and to point to the directions of the cross-border cooperation in the area concerned in the years 2014-2020. The territorial reach of the research is determined by the, so-called, areas of support, designated for the purposes of the Cooperation Programme Interreg VA ${ }^{8}$ and covering: on the Polish side - West Pomeranian Voivodeship, and the two lands on the German side Mecklenburg-Vorpommern and Brandenburg. In the article, a 'desk research' method as well as literature and document analyses were used. As a complementary method,

\footnotetext{
N. Varhove, Regional Policy: A European Approach, Avebury, Aldershot 1999, p. 122.

4 See generally C. Osękowski, H. Szczegóła, Pogranicze polsko-niemieckie w okresie transformacji (1989-1997), WSP, Zielona Góra 1999.

5 G. Gorzelak, Granica polsko-niemiecka - od napięcia do współdziałania w ramach programu wspótpracy transgranicznej Unii Europejskiej, in: Nowe granice Unii Europejskiej - wspótpraca czy wykluczenie, eds. G. Gorzelak, K. Krok, Wydawnictwo Naukowe Scholar, Warszawa 1996, p. 236.

6 Within the framework of sub-programme Phare CBC (Phare Cross-border Co-operation), a part of the Programme PHARE.

7 See M.Greta, Euroregiony polskie w procesie integracji europejskiej oraz w przezwyciężaniu peryferyjności i dysproporcji regionalnych, Wydawnictwo Uniwersytetu Łódzkiego, Łódź 2013, p. 221-225.

8 Cooperation Programme Interreg VA Mecklenburg-Vorpommern/Brandenburg - Poland within the framework of the "European Territorial Cooperation" go of the European Regional Development Fund (ERDF), final project of 2 December 2014.
} 
paper and pencil interviews with the representatives of the Pomeranian Euroregion were carried out.

\section{Barriers to the cross-border cooperation in the northern part of the Polish-German borderland}

According to the Madrid Convention, cross-border co-operation is any concerted action designed to reinforce and foster neighbourly relations between territorial communities or authorities within the jurisdiction of two or more states. ${ }^{9}$ The main purpose of cross-border cooperation is to wipe out barriers and limitations (both formal and mental) located on both sides of the border. It is about finding the way to solve problems together and to coexist in peace. ${ }^{10}$

Barriers to cross-border cooperation are such factors that have a negative impact on it. In this case, they act as the barriers limiting the social and economic development of the borderlands. ${ }^{11}$ There are various classifications of barriers to cross-border cooperation that can be found in the literature concerned with this subject. With regard to their nature, they can be divided into, inter alia, formal and legal, institutional, infrastructural, financial, economic, social, or environmental. ${ }^{12}$ It must not be forgotten that every border region is different, and is characterised by specific circumstances, hence the exact nature of the barriers to the cross-border cooperation should be identified precisely for the given area studied.

Based on the research performed, the most significant barriers that hinder and affect negatively the development of the northern part of the Polish-German borderland (Table 1) were singled out to the cross-border cooperation between West Pomeranian Voivodeship on one side, and Mecklenburg-Vorpommern/Brandenburg on the other side.

The barrier related to the unfavourable location of the areas studied has much to do with their peripherality. The problem of peripherality stems from the fact that the presence of the larger or smaller regional irregularities is the feature of every economic system. ${ }^{13}$ However, in the case of the Polish-German border, we deal with the largest asymmetry

9 European Outline Convention on Transfrontier Co-operation between Territorial Communities or Authorities, made in Madrid on 21 May 1980, O.J. 1993, no. 61.

10 K. Tomaszewski, Regiony w procesie integracji europejskiej, Wolters Kluwer, Kraków 2007, p. 112.

11 Ł. Lewkowicz, Euroregiony na pograniczu polsko-stowackim. Geneza i funkcjonowanie, Wydawnictwo Uniwersytetu M. Curie-Skłodowskiej, Lublin 2013, p. 27.

12 See S. Ciok, Wplyw granicy $i$ wspólpracy transgranicznej na rozwój lokalny i regionalny zachodnich obszarów przygranicznych, in: Rola granicy $i$ wspótpracy transgranicznej $w$ rozwoju regionalnym $i$ lokalnym, eds. A. Mync, R. Szul, Wydawnictwo Europejskiego Instytutu Rozwoju Regionalnego i Lokalnego, Uniwersytet Warszawski, Warszawa 1999, p. 178-181.

13 A. Olechnicka, Regiony peryferyjne w gospodarce informacyjnej, Centrum Europejskich Studiów Regionalnych i Lokalnych UW, Wydawnictwo Naukowe Scholar, Warszawa 2004, p. 54. 
in the socio-economic development among all the internal borders of the EU. ${ }^{14}$ Additionally, it should be remembered that the regional disparities in the area studied do not only characterize the external system (namely the Polish-German borderland), but also the internal system (centre-periphery). ${ }^{15}$ In 2013, the GDP in West Pomeranian Voivodeship was approx. EUR 8.3 thousand per capita, which accounted for $84.6 \%$ of the Polish average. In the German districts, the GDP per capita ranged between EUR 16.4 thousand and EUR 22 thousand (which accounted for 50\% and 70\% of the federal average). ${ }^{16}$ As the Community's regional policy is being implemented, the regional disparities are gradually decreasing although they still linger.

Apparently, the barrier related to the location of the border areas substantially determines the economic limitations. As for the other important economic barriers to the development of the cross-border cooperation in the area studied, there are three aspects that are discussed. The first of them concerns the unfavourable changes in the labour market. They are mainly the consequences of the labour force migration, and the dropping numbers of the young and qualified staff. In West Pomeranian Voivodeship alone, $6.2 \%$ of the inhabitants stayed outside the country for more than three months in 2011. As compared with 2002, that share grew as much as four times. ${ }^{17}$ The second aspect is that of the unfavourable changes which have taken place in the structure of West Pomerania's and Vorpommern's economies in the last decades, particularly with regard to the collapse of the shipbuilding industry. This sector was the essential element of the maritime economy of both Poland and Germany, hence the effects of these changes will continue to be experienced in the area concerned for a long period to come.

Negative demographic changes are considered another type of the significant barriers to the cross-border cooperation in the northern part of the Polish-German borderland. The area concerned has a population of 2.9 million, of which 1.7 million live on the Polish side. ${ }^{18}$ The population decline and ageing is larger on the German side. It is estimated that the number of the inhabitants of the German border area studied will have fallen by approx. $15 \%$ by 2030 , as compared to 2010 . This trend will be accompanied by the in-

14 J.W. Scott, K. Collins, Including transboundary regionalizm in asymmetric situations: The case of the German-Polish border, "Journal of Borderlands Studies" 1997, vol. 12, no. 1/2, p. 97-121; ESPON, Atlas. Mapping the structure of the European territory, European Spatial Planning Observation Network, Bonn 2006.

15 See, e.g., A. Malkowski, Wschodnia granica Polski. Od Peryferii i izolacji do współdziałania, in: Polityka ekonomiczna, eds. J. Sokołowski, G. Węgrzyn, Prace Naukowe UW we Wrocławiu no. 307, Wrocław 2013, p. 364-366.

16 Program Wspótpracy INTERREG VA..., p. 8.

17 M. Matkowska, Emigracja z województwa zachodniopomorskiego w świetle Narodowego Spisu Powszechnego 2011 roku, in: Gospodarka regionalna i międzynarodowa, vol. 2, eds. B. Kryk, H. Nakonieczna-Kisiel, Studia i Prace Wydziału Nauk Ekonomicznych i Zarządzania no. 33, Wydawnictwo Naukowe Uniwersytetu Szczecińskiego, Szczecin 2013, p. 148.

18 Data for 2012 according to Eurostat. 
creasing shares of elderly people. Almost $40 \%$ of the German population living in the area studied will be over 65 in $2030 .{ }^{19}$ As for West Pomeranian Voivodeship, the population projection for 2030 estimates a fall of $1.8 \%$, as compared to $2010 .{ }^{20}$

Table 1. Barriers to the cross-border cooperation in the northern part of the Polish-German borderland

\begin{tabular}{|c|c|}
\hline Type of barrier & Areas with limitations \\
\hline Location barrier & $\begin{array}{l}\text { peripheral location of the Polish border area and the German border area } \\
\text { regional disparities }\end{array}$ \\
\hline Economic barriers & $\begin{array}{l}\text { unfavourable changes in the labour market } \\
\text { structural transformations in the region's economy } \\
\text { unfavourable structure of businesses }\end{array}$ \\
\hline Social barriers & $\begin{array}{l}\text { depopulation } \\
\text { increasing share of elderly people } \\
\text { insufficient progress in developing and implementing shared educational } \\
\text { objectives }\end{array}$ \\
\hline Infrastructural barriers & $\begin{array}{l}\text { the maritime hub within the Trans-European Transport Network has an insufficient } \\
\text { number of cross-border connections }\end{array}$ \\
\hline $\begin{array}{l}\text { No feedback: science - research } \\
\text { institutes - economy (practice) }\end{array}$ & $\begin{array}{l}\text { the available potential of higher education institutions and research institutes is not } \\
\text { utilized by the economy to a sufficient extent }\end{array}$ \\
\hline Language barrier & $\begin{array}{l}\text { the level of command of the neighbour's language is insufficient for fluent } \\
\text { communication }\end{array}$ \\
\hline Historical and cultural barriers & $\begin{array}{l}\text { lack of knowledge of the history and mentality, as well as a sceptical approach } \\
\text { and prejudice on both sides of the Polish-German border }\end{array}$ \\
\hline Legal and administrative barriers & $\begin{array}{l}\text { insufficient knowledge of the structure of the administration and the administrative } \\
\text { culture of the neighbour } \\
\text { different legal conditions }\end{array}$ \\
\hline Financial barriers & $\begin{array}{l}\text { financial problems of the local governments that hinder the long-term cross-border } \\
\text { cooperation }\end{array}$ \\
\hline Environmental barriers & $\begin{array}{l}\text { conflicts between different forms of tourism and the need to protect } \\
\text { the environment and nature }\end{array}$ \\
\hline No leader & $\begin{array}{l}\text { Szczecin, predestined to the leader's role, has not consolidated its position } \\
\text { in the Polish-German borderland so far }\end{array}$ \\
\hline
\end{tabular}

Source: the author's own study on the basis of: Transgraniczna Koncepcja Rozwoju i Działania Euroregionu Pomerania na lata 2014-2020. Aktualizacja, the Association of the Polish Municipalities in the Pomerania Euroregion - Kommunal gemeinschaft Europaregion Pomerania e. V., Szczecin-Löcknitz 2009, p. 9, 54; Program Współpracy INTERREG VA..., p. 7-14; P. Bartnik, Euroregionalny wymiar EUWT, w: Nasze pogranicze - między wizją a praktyką, Post-conference materials, Szczecin 2011, p. 39.

Another of the barriers identified is related to the communication infrastructure. The sea harbours (in Szczecin, Świnoujście, Police, and Saßnitz), as well as the airports (in Heringsdorf and Szczecin-Goleniów), which are situated within the borderland con-

19 Transgraniczna Koncepcja..., p. 6-7.

20 Author's own calculations based on: Prognoza ludności na lata 2014-20150 - województwa, GUS, http:/stat.gov.pl/obszary-tematyczne/ludnosc/prognoza-ludnosci/prognoza-ludnosci-na-lata-2014-2050-opracowana-2014-r-, 1,5.html. 
cerned, are expected to play a significant role in building the Trans-European Transport Network. The network is supposed to provide the access to all regions of the European Union, including the peripheral and the most distant ones. However, the following (and more) infrastructural problems have been indicated within the area in question: 1) too few, low quality, and hardly attractive cross-border railway connections; 2) the presence of natural barriers to the development of the local road network (bodies of water and rivers along the border); 3 ) the necessity of renovating and eliminating cross-border bottlenecks; 4) the necessity of ensuring better cross-border connections with the A20/A11 motorway; 5) difficulties in providing and maintaining the public transport offer.

The barrier related to the road infrastructure also hinders the cross-border cooperation between enterprises. The significance of the road transport is particularly noticeable when looking at the investment locations chosen by German businesses. German corporations clearly favour locating their plants near motorway hubs (e.g. Poznań, Wrocław), which is especially true of the automotive industry. ${ }^{21}$ Therefore, Szczecin is omitted in this respect. This is confirmed by the statistical data concerning direct investments in Poland. Germany is Poland's third largest investor, with its share in foreign capital amounting to $16.9 \%$ in 2012 . Polish voivodeships' proximity to the Polish-German border is not the major criterion when it comes to selecting locations for German investments. In 2012, the largest number of German investments went to Masovian Voivodeship (35.8\%). West Pomeranian Voivodeship, which is directly adjacent to the border, attracted even less investment (merely 2.7\%) than the distant Pomeranian Voivodeship (3.4\%). ${ }^{22}$

Moreover, it is indicated in the strategic documents for the area studied that the available potential of the higher education institutions and the research institutes is not utilized by the economy to a sufficient extent. This may in turn hamper the development of the innovative processes, and determine the region's lower competitiveness. ${ }^{23}$ Only innovative regions can compete with others successfully. Innovation, in turn, depends on the skills and the capacities of the public and private sector entities to produce innovation, and on the efficiency of the region's technology transfer system. ${ }^{24}$ Technopark Pomerania, opened in March 2015 in Szczecin, is certainly one answer to that barrier, as its objective is to support the development of innovative entrepreneurship.

${ }^{21}$ Wspótpraca gospodarcza Polska-Niemcy, eds. B. Wyżnikiewicz et al., Instytut Badan nad Gospodarką Rynkową, Warszawa 2014, p. 30.

22 Ibidem, p. 23.

${ }^{23}$ Cf. A. Malkowska, A. Malkowski, Konkurencyjność obszarów peryferyjnych na przykładzie pogranicza polsko-niemieckiego,"Journal of Agribusiness and Rural Development” 2011, no. 2 (20), Wydawnictwo Uniwersytetu Przyrodniczego w Poznaniu, p. 55-63.

${ }^{24}$ See generally J. Chądzyński, A. Nowakowska, Z. Przygodzki, Region i jego rozwój w warunkach globalizacji, CeDeWu, Warszawa 2007, p. 142-148. 
Nevertheless, it should be highlighted that research and development can be also carried out by enterprises on their own. Unfortunately, the area concerned is dominated by micro and small businesses, which do not have the required capital and resources to do it. Besides, it has been indicated that the firms operating in this part of the borderland analysed are hardly orientated towards the so-called sunrise industries, and that the area is experiencing a deficit of the cross-border transfer of knowledge and innovation. As it comes to the cooperation between enterprises in respect of technology, the following fields should be indicated: plasma physics, biotechnology, and energy technology. ${ }^{25}$

Language is still one of the problems encountered in this area. ${ }^{26}$ The language barrier makes joint projects more difficult, and is a considerable obstacle to the local community integration. However, it is worth noting that the share of the pupils and students learning German amounts to $63 \%$ in West Pomeranian Voivodeship (while the Polish average is $46 \%$ ), which places the region in the second position in Poland (behind Lubuskie Voivodeship with its share of $67 \%$ ). ${ }^{27}$

The activities aimed at bringing the cultures together and getting to know the others' identity and customs are yet another aspect of the cross-border cooperation. However, their purpose is not to eliminate the differences, but to facilitate mutual understanding and the establishment of good social contacts. ${ }^{28}$ In the area concerned, this is still a difficult job to do, as the region was one of those that suffered most in terms of the destruction of the regional identity resulting from the post- 1945 border shifts, and from the experiences of communism which rejected the integration between the societies. Therefore, the process of building the sociocultural identity is not yet complete here. ${ }^{29}$

Administrative and legal barriers are considered to be essential obstacles to the crossborder cooperation. Here, the following limitations are discussed: long decision-making procedures (at all levels: EU, governmental, or voivodeship/land), or the necessity to invest a huge administrative effort while completing common projects. Another problem lies in how Polish and German entities work together - they meet and discuss issues, but in their thinking they often stop at the 'border'. ${ }^{30}$

25 See Transgraniczna Koncepcja..., p. 54.

${ }^{26}$ Cf. A. Greta, Euroregiony polskie..., p. 222-225.

27 A. Braunek, Powszechność nauczania języków obcych w roku szkolnym 2011/2012, Ośrodek Rozwoju Edukacji, Warszawa 2013, p. 27, 34.

28 W. Malendowski, M. Ratajczak, Euroregiony. Polski krok do integracji, Alta 2, Wrocław 1998, p. 39.

29 C. Trosiak, Zagadnienie tworzenia się tożsamości regionalnej na Ziemiach Zachodnich i Pótnocnychprzyczynek do dyskusji, in: Pogranicze polsko-niemieckie po roku 2004. Nowa jakość sąsiedztwa?, eds. J. Jańczak, M. Musiał-Karg, Wydawnictwo A. Marszałek, Toruń 2009, p. 23, 25.

30 P. Bartnik, Euroregionalny ..., p. 39. 
The cooperation in the northern Polish-German borderland is also hampered by financial barriers. The level of affluence ${ }^{31}$ is the basic problem in the cross-border cooperation, as it determines the so-called own contribution of the entities, mainly local governments, which is required to be carried out for EU projects.

In the event of environmental barriers in the area concerned, the attention is drawn to the potential conflicts between the development of tourism and the purposes of environmental protection. Tourism is one of the main directions of the development of the Polish-German borderland area. ${ }^{32}$ Therefore, in the years 2014-2020, the emphasis is to be put on supporting the tourism based on the cultural and the natural heritage.

The last but not least barrier to the cross-border cooperation in the area analysed herein is the lack of leadership. Leadership is the important element of the majority of processes. Szczecin is predestined to the leader's role. Nevertheless, the efforts to make Szczecin the metropolis development leader for the Polish-German border area have been fruitless so far. ${ }^{33}$ It is indicated that Szczecin must pursue the consolidation of its position as the centre of the cross-border area, which will be in the interests of the broadly-defined development of the entire area of the northern Polish-German borderland. ${ }^{34}$

\section{Directions of the cross-border cooperation in the northern part of the Polish-German borderland in 2014-2020}

The identification and the awareness of the existing barriers should be of crucial importance from the point of view of programming the directions of the cross-border cooperation and the funds for their implementation. According to Interreg VA, the cooperation in the Polish-German borderland between 2014 and 2020, between West Pomeranian Voivodeship and Mecklenburg-Vorpommern/Brandenburg is expected to focus on four strategic domains: cross-border cooperation, education, transport and mobility, and nature and culture. A total of EUR 157 million has been earmarked for those purposes, of which the most (32\% each) for the priorities I and IV (Table 2).

The objective of the 'cross-border cooperation' priority is to "enhance institutional capacity of public authorities and stakeholders and efficient public administration by promoting legal and administrative cooperation and cooperation between citizens and institutions." 35 Joint

31 K. Szmigiel-Rawska, S. Dołzbłasz, Trwałość wspótpracy przygranicznej, CeDeWu, Warszawa 2012, p. 47.

32 See A. Malkowska, Program INTERREG IVA jako instrument wspierania turystyki w Województwie Zachodniopomorskim, in: Polityka ekonomiczna, eds. J. Sokołowski, A. Żabiński, Prace Naukowe Uniwersytetu Ekonomicznego we Wrocławiu, no. 348, Wrocław 2014, p. 181-189.

33 P. Bartnik, Euroregionalny..., p. 39.

34 Transgraniczna Koncepcja..., p. 22.

35 Cooperation Programme INTERREG VA..., p. 73. 
actions should deepen and broaden the scope of the cross-border structures of the cooperation and networking. The objective of the networking is to determine, inter alia, the development of Szczecin Metropolitan Area, the development of the common economy and the labour market area, and the expansion of the cross-border educational networks.

Table 2. Division of funds under the Cooperation Programme Interreg VA Mecklenburg-Vorpommern/ Brandenburg-Poland for the years 2014-2020

\begin{tabular}{|c|c|c|c|c|}
\hline \multirow{2}{*}{ Priority axis } & \multirow{2}{*}{$\begin{array}{l}\text { UE support } \\
\text { (EUR mn) }\end{array}$} & \multirow{2}{*}{$\begin{array}{l}\text { National } \\
\text { contribution } \\
\text { (EUR mn) }\end{array}$} & \multicolumn{2}{|c|}{ General subsidy } \\
\hline & & & (EUR mn) & $(\%)$ \\
\hline Cross-border cooperation & 42.88 & 7.57 & 50.45 & 32 \\
\hline Education & 13.40 & 2.36 & 15.76 & 10 \\
\hline Transport and mobility & 26.80 & 4.73 & 31.53 & 20 \\
\hline Nature and culture & 42.88 & 7.57 & 50.45 & 32 \\
\hline Technical support & 8.04 & 1.42 & 9.46 & 6 \\
\hline Total & 134.0 & 23.65 & 157.65 & 100 \\
\hline
\end{tabular}

Source: author's own study on the basis of Cooperation Programme INTERREG VA..., p. 73.

Within the second strategic domain entitled 'education', the actions are focused on "investing in education, training and vocational training for skills and lifelong learning." ${ }^{36}$ This priority addresses directly the border area inhabitants. Its purpose is to develop human resources by the community acquiring new competences or language skills.

"Promoting sustainable transport and removing bottlenecks in the key network infrastructure" ${ }^{37}$ is the objective of the third strategic domain, namely 'transport and mobility'. The cross-border cooperation within the framework of this priority is expected to contribute to the improvement of the quality of the connections within the TransEuropean Transport Network in the region, and to the development of the cross-border transport systems, while taking into account the demographic and spatial structure.

"Preservation and protection of the environment, as well as promoting effective resource management" 38 is the objective of the fourth strategic domain "nature and culture' within the Programme Interreg VA. It is in protecting, promoting, and developing the natural and cultural heritage where the opportunity is seen for strengthening the identity of the inhabitants of the region, and for the development of tourism in the PolishGerman borderland.

\footnotetext{
36 Ibidem.

37 Ibidem.

38 Ibidem.
} 


\section{Summary}

After over two decades of the cross-border cooperation in the northern part of the Polish-German borderland, the barriers to joint operations still exist there, thereby negatively affecting the socioeconomic development of that area. Based on the literature analyses, the conclusion can be drawn that the nature of those barriers and their impact have been changing in time. Assessing the 'strength' of the particular factors is a difficult job, nevertheless, the interviewees put a very strong emphasis on the limitations with regard to such aspects as language, leadership, the affluence of the local governments, and innovation. Therefore, these barriers should currently be considered as the largest from the point of view of the cross-border cooperation and its effect on the development of the northern part of the Polish-German borderland.

The barriers that have been singled out, as well as the limitations related to them, are found in various fields of the cooperation. It is essential that they be eliminated, if that is possible, in the first place, or that their negative effects be mitigated. This should be facilitated by the funds allocated under the Cooperation Programme Interreg VA. The most important directions set by this programme for the years 2014-2020 are: economic, social, legal, and administrative cooperation, building Szczecin Metropolitan Area, the protection of the environment, as well as the historical and the cultural heritage, tourism, communication infrastructure, science and higher education, and research and development. It appears that these directions of the cross-border cooperation in the area concerned have been marked out correctly, as they are in correlation with the barriers identified. Hence, one should expect that with the completion of the joint Polish-German projects under Interreg VA, the negative effects of the existing barriers, at least partially, will be eliminated.

\section{Literature}

Bartnik P., Euroregionalny wymiar EUWT, in: Nasze pogranicze - między wizja a praktyka, Post-conference materials, Szczecin 2011.

Braunek A., Powszechność nauczania języków obcych w roku szkolnym 2011/2012, Ośrodek Rozwoju Edukacji, Warszawa 2013.

Chądzyński J., Nowakowska A., Przygodzki Z., Region i jego rozwój w warunkach globalizacji, CeDeWu, Warszawa 2007.

Ciok S., Wplyw granicy $i$ wspótpracy transgranicznej na rozwój lokalny i regionalny zachodnich obszarów przygranicznych, in: Rola granicy $i$ wspólpracy transgranicznej $w$ rozwoju regionalnym i lokalnym, eds. A. Mync, R. Szul, Wydawnictwo Europejskiego Instytutu Rozwoju Regionalnego i Lokalnego, Uniwersytet Warszawski, Warszawa 1999.

Dołzbłasz S., Raczyk A., Projekty wspótpracy trans granicznej na zewnętrznych $i$ wewnętrznych granicach Unii Europejskiej - przyktad Polski, "Studia Regionalne i Lokalne" 2011, no. 3 (45). 
ESPON, Atlas. Mapping the structure of the European territory, European Spatial Planning Observation Network, Bonn 2006.

European Outline Convention on Transfrontier Co-operation between Territorial Communities or Authorities, made in Madrid on 21 May 1980, O.J. 1993, no. 61, (287).

Gorzelak G., Granica polsko-niemiecka - od napięcia do współdziałania w ramach programu wspótpracy transgranicznej Unii Europejskiej, in: Nowe granice Unii Europejskiej wspótpraca czy wykluczenie, eds. G. Gorzelak, K. Krok, Wydawnictwo Naukowe Scholar, Warszawa 1996.

Greta M., Euroregiony polskie w procesie integracji europejskiej oraz w przezwyciężaniu peryferyjności i dysproporcji regionalnych, Wydawnictwo Uniwersytetu Łódzkiego, Łódź 2013.

Lewkowicz Ł., Euroregiony na pograniczu polsko-stowackim. Geneza i funkcjonowanie, Wydawnictwo Uniwersytetu M. Curie-Skłodowskiej, Lublin 2013.

Malendowski W., Ratajczak M., Euroregiony. Polski krok do integracji, Alta 2, Wrocław 1998.

Malkowska A., Malkowski A., Konkurencyjność obszarów peryferyjnych na przykładzie pogranicza polsko-niemieckiego, "Journal of Agribusiness and Rural Development" 2011, no. 2 (20).

Malkowska A., Program INTERREG IVA jako instrument wspierania turystyki w Województwie Zachodniopomorskim, eds. J. Sokołowski, A. Żabiński, Polityka ekonomiczna, Prace Naukowe Uniwersytetu Ekonomicznego we Wrocławiu, no. 348, Wrocław 2014.

Malkowski A., Wschodnia granica Polski. Od Peryferii i izolacji do współdziałania, eds. J. Sokołowski, G. Węgrzyn, Polityka ekonomiczna, Prace naukowe UW we Wrocławiu no. 307, Wrocław 2013.

Matkowska M., Emigracja z województwa zachodniopomorskiego w świetle Narodowego Spisu Powszechnego 2011 roku, in: Gospodarka regionalna i międzynarodowa, vol. 2, eds. B. Kryk, H. Nakonieczna-Kisiel, Studia i Prace Wydziału Nauk Ekonomicznych i Zarządzania no. 33, Wydawnictwo Naukowe Uniwersytetu Szczecińskiego, Szczecin 2013.

Olechnicka A., Regiony peryferyjne w gospodarce informacyjnej, Centrum Europejskich Studiów Regionalnych i Lokalnych UW, Wydawnictwo Naukowe Scholar, Warszawa 2004.

Osękowski C., Szczegóła H., Pogranicze polsko-niemieckie w okresie transformacji (1989-1997), WSP, Zielona Góra 1999.

Perkmann M., Building governance institutions across European borders, Regional Studies 1999, vol. 33 , no. 7 .

Prognoza ludności na lata 2014-2050 - województwa, GUS, http://stat.gov.pl/obszary-tematyczne/ludnosc/prognoza-ludnosci/prognoza-ludnosci-na-lata-2014-2050-opracowana2014-r-,1,5.html.

Cooperation Programme InterregVA Mecklenburg-Vorpommern/Brandenburg - Poland within the framework of the "European Territorial Cooperation" goal of the European Regional Development Fund (ERDF), final project of 2 December 2014.

Scott J.W., Collins K., Including transboundary regionalizm in asymmetric situations: The case of the German-Polish border, Journal of Borderlands Studies 1997, vol. 12, no. 1/2.

Szmigiel-Rawska K., Dołzbłasz S., Trwałość wspótpracy przygranicznej, CeDeWu, Warszawa 2012 .

Tomaszewski K., Regiony w procesie integracji europejskiej, Wolters Kluwer, Kraków 2007.

Transgraniczna Koncepcja Rozwoju i Działania Euroregionu Pomerania na lata 2014-2020. Aktualizacja, Stowarzyszenie Gmin Polskich Euroregionu Pomerania - Kommunal gemeinschaft Europaregion Pomerania e. V., Szczecin-Löcknitz 2013. 
Trosiak C., Zagadnienie tworzenia się tożsamości regionalnej na Ziemiach Zachodnich i Pólnocnych - przyczynek do dyskusji, in: Pogranicze polsko-niemieckie po roku 2004. Nowa jakość sąsiedztwa?, eds. J. Jańczak, M. Musiał-Karg, Wydawnictwo A. Marszałek, Toruń 2009.

Varhove N., Regional Policy: A European Approach, Avebury, Aldershot 1999.

Wspótpraca transgraniczna Unii Europejskiej. Doświadczenia polsko-niemieckie, eds. G. Gorzelak, J. Bachtler, M. Kasprzyk, Wydawnictwo Naukowe Scholar, Warszawa 2004.

Wspótpraca gospodarcza Polska - Niemcy, eds. B. Wyżnikiewicz et al., Instytut Badań nad Gospodarką Rynkową, Warszawa 2014.

\begin{abstract}
The purpose of this article is to identify the barriers to the cross-border cooperation in the northern part of the Polish-German borderland at the threshold of the new programming period 2014-2020. Territorially, the research covers: West Pomeranian Voivodeship on the Polish side, and two lands on the German side - Mecklenburg-Vorpommern and Brandenburg. Based on the analysis of the literature and the strategic documents, as well as on the paper and pencil interviews carried out by the author, an attempt is made herein to indicate the largest barriers. Also, the article points to the directions of the cross-border cooperation within the area concerned in the period 2014-2020 that are derived from the Cooperation Programme Interreg VA.
\end{abstract}

Bariery i kierunki współpracy transgranicznej w północnej części pogranicza polsko-niemieckiego

Celem artykułu jest identyfikacja barier współpracy transgranicznej w północnej części pogranicza polsko-niemieckiego, u progu nowego okresu programowania 2014-2020. Zakres terytorialny badań wyznaczaja: po polskiej stronie województwo zachodniopomorskie, a po niemieckiej dwa landy: Meklemburgia-Pomorze Przednie oraz Brandenburgia. Na podstawie analizy literatury i dokumentów strategicznych oraz przeprowadzonych wywiadów bezpośrednich podjęto próbę wskazania, jakie bariery są największe. W artykule wskazano też kierunki współpracy transgranicznej na badanym obszarze w latach 2014-2020, które wynikają z Programu Współpracy Interreg VA. 